\title{
O MAIOR EMPRESÁRIO QUE O BRASIL JÁ TEVE
}

\author{
Por Fábio Luiz Mariotto \\ Professor Titular da FGV-EAESP \\ E-mail: fmariotto@fgvsp.br
}

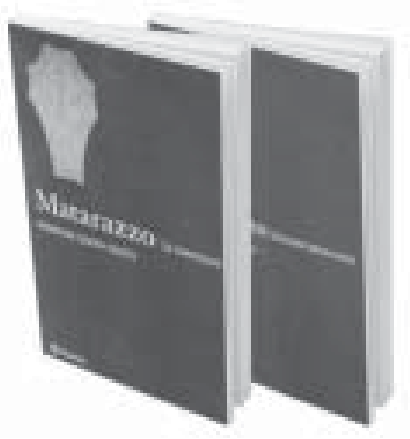

\section{MATARAZZO}

De Ronaldo Costa Couto

São Paulo: Editora Planeta do Brasil, 2004. 332 p. (v. 1) e 407 p. (v. 2).

Talvez a maior contribuição deste sexto livro de Ronaldo Costa Couto seja resgatar a memória do imigrante italiano Francesco Matarazzo, pioneiro da industrialização brasileira, que se tornou o maior empresário do Brasil de todos os tempos ao criar o mais vasto complexo industrial da América do Sul. Nem o visconde de Mauá construiu al go comparável. A lembrança de M atarazzo vem se esvaecendo nas últimas décadas, em grande parte devido ao declínio e à quase extinção do gigantesco grupo econômico que criou, de modo quea evocação queeste livro faz é bem-vinda e merecida. Esta é a mais recente e abrangente biografia de Matarazzo. Há pelo menos três outras biografias dele em forma de livro, dos autores Vincenzo Blancato (1925), José de Souza M artins (1974) eGiovanni Titta Rosa (1994). Nenhu- ma del as étão abrangente quanto esta, de Costa Couto.

O livro conta a saga de Matarazzo e da sua família. Em 1881, com 27 anos, Francesco partiu de Castellabate - cidadezinha medieval 120 quilômetros a sudeste de Nápoles -, com mulher e dois filhos pequenos, com destino ao Brasil. Era de origem burguesa, com antepassados fidalgos, e tinha instrução formal, mas a família na Itália estava empobrecida e ele chegou ao Brasil com muito pouco dinheiro. Começa operando como mascate na região de Sorocaba, SP, conduzindo uma tropa de mulas carregadas de mercadorias que vende no varejo. Poucos meses após sua chegada, ele abre um pequeno armazém de secos e molhados. Já no fim de 1882 começa a fabricar em casa banha de porco, sendo que até então a maior parte da banha consumida no país era importada dos Estados Unidos. No ano seguinte começa a operar uma pequena fábrica de banha. Com esse início modesto, o jovem imigrante parte para uma trajetória fulgurante, que vai torná-lo o maior empresário que o país já teve e um dos homens mais ricos do mundo na sua época. Em 1917, é agraciado pelo rei da Itália, Vittorio Emanuele III, com o título de conde, em reconhecimento por contribuições filantrópicas feitas por Matarazzo naquele país.

0 livro é de leitura prazerosa e envolvente, e suas 654 páginas de texto, em dois volumes, podem ser percorridas sem esforço. Certamente visando um público de leitores amplo, Couto evitou compor o texto em estilo acadêmico, preferindo usar uma linguagem coloquial, mais próxima da 
de um contador de estórias do que da de um historiador. Além disso, adotou uma estrutura pouco convencional, entremeando a narrativa com anedotas, piadas, provérbios chistosos e trocadilhos para divertir o leitor. Alguns leitores poderão achar que ele abusa dessas inserções. $\mathrm{Na}$ verdade, muitas delas são puras digressões, como, por exemplo, uma piadinha fora de propósito sobre Hermes da Fonseca. Outro recurso do autor é intercalar, no relato de eventos passados, curtos flash forwards para o tempo presente, entrevistando al guém que faz um comentário sobre o evento relatado. Esses trechos de entrevista acabam funcionando como um elo eficaz entre passado e presente.

Couto enfrentou o desafio de evitar o tom laudatório num texto cuja el aboração recebeu enorme apoio dos descendentes do biografado e que, na sua versão final, ganhou claramente o nihil obstat do clã. Ele habilmente deixa que os entrevistados expressem a maior parte dos elogios explícitos ao biografado mas, ao mesmo tempo, não se furta de tratar extensivamente detemas melindrosos e potencialmente danosos à memória de M atarazzo, como os conflitos entre ele e o movimento operário, suas ligações com 0 fascismo e a forma como conduziu sua sucessão, possivelmente a causa da posterior desagregação da família e do gradativo declínio do grupo.

Para produzir esta obra, Costa Couto consultou uma vasta bibliografia, além de documentos públicos no Brasil e na Itália, e documentos privados inéditos cedidos pela família. Ainda realizou e gravou mais de 200 entrevistas com cerca de uma centena e meia de pessoas. A contribuição dos depoimentos dados nessas entrevistas para a autenticação da narrativa é duvidosa, já que quase nenhum dos entrevistados foi testemunha ocular dos fatos e a maioria nem conhe- ceu pessoalmente o biografado, falecido em 1937, baseando-se apenas no que ouviu dizer. A escolha de muitos dos entrevistados parece ter-se guiado mais pela sua atual notoriedade do que pela real contribuição do seu depoimento para o enriquecimento e a validação da narrativa. É o caso, por exemplo, do ator Raul Cortez, que, na novela Terra Nostra, interpretou o papel de Francesco Magliano, personagem fictício inspirado em M atarazzo; ou de José Sarney, cuja ligação com M atarazzo permanece um mistério para o leitor. 0 fato de que essas pessoas tenham sido escolhidas para dar depoimentos sugere que Costa Couto está ciente da importância que o grande público atribui às declarações de celebridades. É possível que muita gente acredite mais no que diz uma personal idade famosa do que naquilo que é afirmado num estudo científico. No caso em foco, o efeito final dos depoimentos de notabilidades parece-me ser 0 de reforçar 0 aspecto mítico desta biografia.

Para os estudiosos de Administração, Economia, Política e História, a obra de Costa Couto proporciona uma riqueza de fatos e desdobramentos interessantíssimos. No entanto, o que 0 autor oferece a esses leitores são apenas tira-gostos, já que suas análises de cunho econômico, político ou empresarial são muito superficiais e o que há de análise não raro se perde no meio de uma profusão de matérias puramente recreativas. Os interessados em estudos do comportamento de Matarazzo e do seu grupo sob esses enfoques terão que consultar outras fontes. Como sugestão, posso citar o estudo clássico de Warren Dean, A industrialização de São Paulo: 1880-1945 (1971), e a bela tese de doutorado de Gerald Dinu Reiss, Development of Brazilian Industrial Enterprise: A Historical Perspective (1980) . O primeiro mos- tra o papel desempenhado por Matarazzo na evolução econômica, social e política do setor industrial paulista. No segundo, Reiss caracteriza os vários processos de desenvolvimento industrial que ocorreram no Brasil na primeira metade do século $X X$. De particular interesse é o model o empresarial que Reiss tipificou como "grande empório industrial" e que descreve o padrão de crescimento adotado inicialmente por Matarazzo. 0 modelo permite compreender a lógica econômica da combinação de diversificação com integração vertical, estratégia condenada na literatura corrente, mas que $M$ atarazzo usou na época com enorme sucesso. Costa Couto inclui esses dois estudos na bibliografia do livro, assim como vários outros de teor semelhante.

Com esta obra Costa Couto recupera, de um passado já quase esquecido, a heróica figura de Francesco M atarazzo e sua estupenda obra empresarial. Ao longo de uma narrativa circunstanciada e abrangente, 0 autor vai comunicando ao leitor toda a espantosa dimensão das realizações do biografado, assim como a enorme influência e o prestígio que ele granjeou em vida. E o faz usando uma linguagem típica do campo da mídia e do entretenimento, o que, aliás, atual mente é conveniente para se falar de uma verdadeira celebridade, como foi Matarazzo.

U ma nota sobre o autor: o mineiro Ronaldo Costa Couto é graduado em Economia e já exerceu as profissões de jornalista, pesquisador e professor universitário, além de ter ocupado altos cargos políticos, como os de ministro do Interior, ministro do Trabalho, governador do DF e chefe da Casa Civil da Presidência. Em 1997, obteve o título de doutor em História Contemporânea pela Universidade Paris-Sorbonne (Paris IV). 